\title{
diseases of pLANTS dUE TO FUNGI.
}

\author{
By A. Lorrain Smith.
}

\section{GLOEOSPORIUM TILIAE OUD.}

An instance of loss caused by this fungus was brought under my notice in June of this year. The leaves of some lime trees in Oxfordshire were stripped from the branches in large numbers during a gale of wind. There had been severe cold and frost, which might have injured the leaves; and there had been a hailstorm, which had undoubtedly torn and injured the foliage. These factors, however, did not seem sufficient to account for the damage done, especially as the leaves when they fell were at their fullest vitality. The owner of the trees had noticed black patches on some of the leaves and, on the petioles of those that had fallen, a small burnt-like spot was nearly always present at the point of rupture.

Microscopic examination shewed that the blackened areas were due to the death and discolouration of the cells of the cortex, and on these were seated the small pustules of a Gloeosporium, a fungus belonging to the Melanconieae group of Fungi imperfecti. The injury in some cases had not gone any deeper than the superficial layers of the cortex, in others the mycelium had penetrated to the bundle strand and corroded half-way through the tissue of the stalk. The damage done to the conducting tissue was in no case sufficient to kill the leaf or to sever its connection with the branch, but the weakened petiole was no longer able to resist the force of any strain, and the wind had been the final agent of destruction.

The spots on the leaves were also caused by the same fungus. They were characterized by a central grey portion, visible on both surfaces, the decolouration being caused by the parasite having destroyed the contents of the cells; the Gloeosporium pustules looked like tiny blisters scattered over the discoloured spots : a dark line surrounded each patch.

Gloeosporium, like other Melanconieae, does not form a definite fruiting body. The one-celled spores are borne at the tips of short upright hyphae, which rise from a compacted base of fungal hyphae, localized in little masses and formed under the epidermis of the host plant. The swelling of the epidermis, which bursts at a definite central point to allow the escape of the spores, gives, however, more or less the appearance of a perithecium. The size of the spores found on the Oxfordshire specimens varies very much. They measure about 10 $\mu \times 2 \frac{1}{2} \mu$, some being much smaller. It has been recorded from Holland, Italy and Australia, but only on the blade of the leaf, where it 
is comparatively harmless. A similar fungus appears on the young shoots, leaves and fruits of the vine, causing extensive damage. Another, Gl. nervisequium, attacks the leaves of the Plane; the mycelium passes down the veins into the petiole, and results there also in the fall of the leaf, but in a slightly different way, as no pustules appear on the leaf stalk.

\title{
8EPTORIA FRAGARIAE.
}

This fungus, one of the Sphaeropsideae, also in the group of "Fungi imperfecti," is recorded on the leaves of Fragaria and other allied plants. It occurs on brown spots, the perithecia are very minute and open by a wide pore. A cultivated strawberry was brought to me as one of a crop that had been very much damaged and rendered unfit for market. I had no leaves to examine, but the bracts were covered with the perithecia of the fungus. The strawberry itself was ripe and well formed, but here and there all over it were withered spots. The seeds were very hard and the tissue all round dried and juiceless. Perithecia of Septoria were found there also and were undoubtedly the cause of the injury to the fruit. There was a rich growth of mycelium in the cells beneath the damaged spots. The spores are elongate-cylindrical, 3-septate and colourless, and measure about $35 \mu \times 4 \mu$. There is no size recorded in the published description. There is no record that I can find of the fungus having passed from the leaves to the fruit. The fruits came from a grower near Southampton, but I was unable to get sufficient material to carry out a more complete investigation.

\section{NOTES ON FUNGI REOENTLY OOLLEOTED.}

\author{
By A. Lorrain Smith.
}

Gonytrichum caesium Nees. This somewhat rare fungus was collected in the Autumn on sticks in a Dumfriesshire wood. In several details it differs from the published and figured specimens and yet is so near akin that it is evidently the same species. The brown filaments are intricately branched, tapering and colourless at the tips about $2.5 \mu$ in diameter; a few septa are faintly visible. The conidiophores are bottle-shaped up to $8 \mu$ in length by $3 \mu$ at the widest part, and they cluster round the nodes and at intervals along the branches. The swelling at the nodes is barely perceptible, or altogether absent. The globose 